\title{
IMPROVING THE USEFULNESS OF ACCOUNTING Data in Financial Analysis
}

\author{
Adrian Saville ${ }^{1}$ \\ Gordon Institute of Business Science, University of Pretoria
}

\begin{abstract}
Accounting practices are flawed. As a consequence, the accounting data generated by firms are generally open to interpretation, often misleading and sometimes patently false. Yet, financial analysts place tremendous confidence in accounting data when appraising investments and investment strategies. The implications of financial analysis based on questionable information are numerous, and range from inexact analysis to acute investment error. To rectify this situation, this paper identifies a set of simple, yet highly effective corrective measures, which have the capacity to move accounting practice into a realm wherein accounting starts to 'count what counts'. The net result would be delivery of accounting data that more accurately reflect firms' economic realities and, as such, are more useful in the task of financial analysis.
\end{abstract}

JEL M41, 42

1

\section{Introduction}

Some see things as they are and ask why. Others dream things that never were and ask why not.

- George Bernard Shaw

The past five years have witnessed a surge in the incidence of exposed accounting irregularities and frauds. Examples abound internationally and domestically. ${ }^{2}$ Whilst the country, industry and business detail behind these errant entities varies, the cases all share a common harmful ailment: accounting irregularities which have catalysed business failure. These accounting failures, in turn, have translated into massive destruction of investor wealth. ${ }^{3}$ Further to this, international evidence reveals that the number and size of companies restating financials to disclose accounting irregularities and frauds is growing with time (Floyd, 2003: 5-7).

One consequence of the above is that investors have intensified their questioning of accounting practices, with the interrogation revolving around the reliability of accounting data and the usefulness of such information in financial analysis. In many cases, the verdict has been scathing, with a host of writers suggesting that accounting information is highly variable in 'reliability'. In this vein, some observers have gone on to suggest that, as a consequence of this variability, accounting information is frequently of little or no use to the financial analyst. Indeed, at least one commentator has complained that 'published accounts are utterly and absolutely useless' (Holmes \& Sugden in Griffiths \& Wall, 2001: 54).

Against this backdrop, this paper examines four questions relating to the usefulness of accounting data to the financial analyst. First, in Section 2, the paper seeks to establish the principal applications of accounting data and identify the primary data needs in financial analysis. Second, given the various data applications identified, Section 3 considers which data inputs are of greatest relevance to the financial analyst. From this base, the following section identifies problems encountered in applying accounting data in financial analysis. The upshot of this search is unambiguous: accounting data are found to be fraught with problems that have the capacity to negate the use of such data in financial analysis. Accordingly, in Section 5, some effort is made to identify possible solutions available to the 
financial analyst concerned with the application of accounting data. Section 6 is devoted to concluding remarks.

\section{2}

\section{Importance and Applications of Accounting Data}

Before considering the various applications of accounting data, it is worth providing a brief comment on the perceived importance of the information. In this regard, many groups of market participants consider accounting data to be central to the process of investment decision making. For example, in studies conducted in the United States (US) and United Kingdom (UK), investment professionals are found to regard financial statements as the most important source of information in investment decisions (Arnold and Moizer, 1984; Arnold, Moizer and Noreen, 1984). Research conducted into the South African investment environment is congruent with international findings. For instance, Van Rensburg and Fouche (1999), Clackworthy (2000) and Stainbank (2003) all find that investment managers rely principally on accounting data to inform investment decisions.

Against this backdrop of the importance given to accounting data, it is useful to note the applications of accounting data in financial analysis. For the purpose of this paper, five sets of applications are identified. First, accounting data are used by the analyst to appraise the condition of a business. Four main types of evaluation fall into this group: comparison of statements for an enterprise between successive years; comparison of a firm's statements with those of competitors; comparison of a firm against an industry standard; and comparison of a firm's position with a target, such as a financial budget. Second, analysts employ accounting data to forecasting business prospects and evaluate the health of the business. Under the task of forecasting, financial statement analysis usually means the careful extraction of meaningful ratios from accounting statements. The most common ratios employed measure liquidity, activity, profitability and leverage (Kiesco \& Weygandt, 1982). Third, one of the central tasks of the investment analyst is to judge the merits of an investment. In undertaking this task, accurate accounting data typically serve as crucial inputs into valuation models. In this way, accounting data are used either to verify valuations or as a platform for forecasting input values (such as earnings or cash flow per share). Fourth, changes in the business environment invariably impact upon business outcomes. Thus, accurate forecasting of financial outcomes requires analysts to build reliable models of financial sensitivities to environmental variables (such as macroeconomic factors) as a platform for generating dependable financial forecasts. Fifth, accounting data are also used by the analyst to assess the merits of different investment strategies within asset classes as well as across asset classes. In these tasks, accounting data serve a central function by facilitating analysis within and across asset classes. For example, accounting data provide the basis for comparison of relative value of different asset classes. ${ }^{4}$

From the above review, it is apparent that the set of tasks for which accounting data are employed is wide ranging and of considerable importance in the investment process. However, for these tasks to be undertaken with any degree of dependability, three conditions are necessary. First, the accounting data engaged in the task of financial analysis must be accurate and reliable. Second, forecasts of variables used in financial analysts' models must be efficient, that is, unbiased. Third, the models used in analysis and valuation must be robust.

Unfortunately, problems arise at each of these three stages of financial analysis. Data are often inaccurate and, so, unreliable. Further, analysts' forecasts are inefficient, containing various biases which compound the problems introduced by poor data (Warwick, 2000: 6364). ${ }^{5}$ Further, the models used in the task of financial analysis often are incomplete. ${ }^{6}$ The net result is that financial analysts' outputs potentially are corrupted by various sources of error. This undermines analysts' ability to conduct meaningful research and generate reliable results. Following on from this 
argument, improved financial analysis requires that the errors introduced at each level of investigation are remedied. However, this paper focuses only on what might be termed 'stage one error', namely error introduced by accounting data. Two main reasons are given for this focus. First, there is a broad and growing body of international evidence which suggests that improved accounting standards reduce forecast error and promote forecast symmetry (Peek, 2000; Curtis \& Hayes, 2002; Hope, 2002). Thus addressing stage one error is necessarily a first step to correcting forecast error. Second, in the absence of improved data and forecasts, efforts to generate enhanced models are superfluous. As the old adage attests: garbage in, garbage out. ${ }^{7}$ However, before contemplating the issue of data error it is useful to first ascertain which accounting information is of greatest relevance to the financial analyst.

\subsection{Data requirements: market and accounting data}

At the broadest level, it is possible to divide data used by the financial analyst into two categories, namely 'market data' and 'accounting data'. Market data are defined as data established by the market forces of supply and demand. Examples include market capitalisation, beta, discount rate and dividend yield data. Given that data in this category are derived from market outcomes, there is an inclination to assume that the information is 'error free'. However, this is not necessarily the case. First, accounting-based error may play a role in influencing market data. By way of illustration, overstating earnings figures could result in stock price fluctuations that are greater than would have otherwise been the case. Using this example, a positive correlation then would arise between earnings overstatement and a stock's beta. Nevertheless, in the case of market data, the scope for accounting-based errors to influence the quality of information is arguably significantly diminished (when compared to accounting data). That said, and second, even if all tainting caused by accounting-based error were to be eliminated from market data, measurement problems persist. This is often a consequence of market imperfections. For instance, in using the widely-recognised capital asset pricing model (CAPM) to establish equilibrium asset values, various problems have been identified in the measurement of essential market data inputs such as stocks' betas, the risk premium on equities and the risk free-free rate of interest. ${ }^{8}$ However, given the limited role played by accounting error in 'causing' market data measurement error, detailed consideration of market data problems is beyond the scope of this paper. Accordingly, the discussion turns to focus on the second data category, namely accounting data.

Accounting data are defined as data drawn from financial statements, which typically include four main statements, namely the income, cash flow and change in equity statements and the balance sheet. A host of accounting data can be drawn from these statements. The data types range from line items - such as turnover and cash flow - to figures calculated from accounting data - which include a plethora of financial ratios, such as liquidity, profitability and activity ratios. For the sake of clarity, the first type of data is labelled 'basic accounting data' and the second data sort is labelled 'financial accounting data'. Whilst the sets each contain extensive inventories of data, lists of the most commonly used accounting data are provided by Mulford and Comiskey (2002).

Basic accounting data normally are presented in easily accessible format in business's financial statements. Moreover, the required financial accounting data are established from readily calculated formulae. At first glance, then, the task of gathering basic accounting and financial accounting data would seem to be straightforward. However, as intimated in the introduction of this paper, various problems arise in the production of such data that may erode or even eradicate the usefulness of accounting data to the financial analyst. At least two broad-based sets of problems emerge in attempting to employ accounting data in financial analysis. These problems, and their implications, are explored in Section 3. 


\section{3}

\section{Data Error in theory and practice}

\subsection{Data error in theory}

Accounting data suffer from a host of problems that result in the data being of changeable - and even questionable - value to the analyst. In the most extreme form, the data are corrupted by fraudulent accounting practices. Less severe forms of accounting data manipulation lie within the parameters of the law and accepted accounting principles. But presentation of the figures makes interpretation and application complex due to the myriad of rules that allow accountants to present the same situation in the manner most preferred by the firm (Mulford \& Comiskey, 2002). In this regard, however, it is possible to categorise data problems by source, namely sources external to the firm and sources internal to the firm.

External impacts that cause accounting numbers to vary from reported figures - either through time or at a point in time - typically relate to reassessment, or revaluation, of a firm's financial position. External reassessment of a firm's financial position would normally affect balance sheet items. One such cause could be the alteration by regulatory authorities of the status of a firm's tax assets or liabilities. External revaluation may also influence the reliability of a firm's financial statements by causing reported and realisable values to differ. For example, a decline in asset prices (which could affect the value of a tangible asset, such as undeveloped land) may be unreported and so unrecorded in a business that carries the investment at book value. Further, even where assets or liabilities are marked to market, regular fluctuations in prices (values) may make the task of 'accurate' reporting impossible. Changes to accepted accounting principles may also have the effect of causing past information to be inaccurately recorded and so 'incorrectly' reported. Admittedly, in the case of external sources of variation, accountants may have little or no influence on the discrepancy that arises between a firm's actual and reported situations. In most instances, however, accountants are in a position at least to inform analysts of accounting policy and potential impacts of valuation adjustments.

Numerous internal sources of variation in accounting data exist. The most commonly observed sources include:

- variations, inconsistencies and inaccuracies in reporting standards and policies (depreciation practices stand out as an obvious example);

- timing differences that cause the period of measurement to vary (such as retailers turnover being measured and reported over a 52-week or 53-week year);

- the application of internal valuation opinion to externally priced assets (where internal assessments are used to value inter alia intangibles, off-balance sheet loans, unlisted investments, derivative instruments and other off-balance sheet items, especially pension funds);

- incomplete acknowledgement (such as failure to report per share dilution in the case of vesting share options and partial cost of capital accounting);

- effects of corporate structural adjustments (which may range from 'legitimate' impacts, such as the effects on reporting of merger or acquisition activity, to 'illegitimate' impacts, such as the use of corporate structure or accounting policy to influence reported data, transfer pricing, 'big bath' restructuring charges and creative acquisition accounting);

- restatement of figures and the use of provisions to manage earnings (caused, for example, by variation in accounting policy from one period to another, or the use of reserves to adjust line items);

- elective concealment (such as a decision not to declare turnover figures as a device for protecting information about market share, using revenue recognition policies to defer or accelerate earnings streams or leaning on 'materiality' practices to influence accounting figures); and

- deliberate misstatement of information (such as over-invoicing). 
With regard to the above list, it is worth stressing that this paper identifies key error sources as being located exclusively in the 'internal sources' category. These sources of error relate to problems arising from partial cost of capital accounting, treatment of pension funds, the use of provisions to manage earnings, depreciation policies and the expensing of stock options.

Before considering the broader ramifications of the above arguments, it is worthwhile to comment briefly on the status of financial accounting data in the milieu. Financial accounting data are a derivative of basic accounting data. So, the same problems identified with regard to basic accounting data are replicated, if not compounded, when generating and interpreting financial accounting data. Put more simply, ratios are subject to the limitations of accounting methods. Moreover, different accounting choices may result in significantly different ratio values. In addition, financial accounting data suffer mainly from three further limitations.

First, a reference point is needed in the use of financial accounting data. To be meaningful, most ratios must be compared to historical values of the same firm, the firm's forecasts, or ratios of similar firms. Second, most ratios by themselves are not highly meaningful. They need to be viewed as indicators, with several ratios combined to paint a picture of the firm's situation. Third, year-end (or interim) statement values are not necessarily representative of firms' positions. For example, certain account balances that are used to calculate ratios may increase or decrease at the end of the accounting period because of seasonal factors. Such changes may distort the value of the ratio.

That aside, and to reiterate, the net effect of the sources of variation or influence on accounting data identified is information that can range across a 'legitimacy spectrum' that spans from 'consistent and highly reliable' to 'fraudulent and patently false'. Unfortunately, the less desirable parts of this spectrum have become increasingly populated over the past two decades - and especially over the past five years - as commercial practices have become increasingly aggressive (despite the fact that in many instances accounting statements practices have become less open to interpretation) and, in some cases, abusive. ${ }^{9}$ Some examples of such cases are offered below to illustrate key points.

\subsection{Empirical evidence of accounting data error}

The empirical evidence relating to accounting data is substantial in size, scope and depth. Indeed, the evidence is sufficiently vast to render it impossible to review in great detail in a paper of this nature. However, reviews of the evidence are provided by other writers, including Kelly (1999) and Levitt (1999). That aside, from a broad perspective, the evidence points to various irregularities that arise in accounting data, including variances in the valuation and treatment of tangible and intangible assets; ${ }^{10}$ artificial inflation of balances sheets and income statements by, for example, bringing un-owned pension fund surpluses into the income statement, over-recording revenue and treating capital items as revenue streams, ${ }^{11}$ and partial reporting of financial positions, such as underrecording costs and over-stating per share figures. ${ }^{12}$

Whilst it is suggest above that detailing individual cases is beyond the scope of this paper, two specific pieces of empirical evidence aid in illustrating the knotty and complicating nature of extant accounting practices. The first - the case of motor vehicle manufacturer Daimler-Benz - highlights problems caused by standards varying across countries. Under German accounting standards, Daimler-Benz reported a profit of 168 million Deutschmarks in 1993. Under US Generally Accepted Accounting Principles (GAAP), the company reported a loss of almost one billion Deutschmarks for the same period (Levitt, 1999). The argument carries into the domestic setting. As recently noted by a leading South African financial publication '... accounting conventions used by companies differ, making it practically impossible to compare and rank companies using their published data' (Financial Mail, 2003: 11). The second piece of evidence relates to the variable reporting practices that suggest firms are highly selective 
about which pieces of information to include in financial statements. Indeed, by the middle of 2001 the majority of companies listed in the Standard and Poor's 500 (S\&P 500) index were excluding certain GAAP expenses in pro forma reporting such that sixty cents on every US\$ of S\&P 500's company earnings reported for the second quarter of 2001 came from excluding costs that would have been included under GAAP.

The implication for the financial analyst is the presentation of accounting data that range from being difficult to interpret to unreliable and, in some instances, simply wrong. In late 1999, in commenting on the quality of financial reporting, Arthur Levitt, former head of the US Security and Exchange Commission noted that 'A culture of gamesmanship over the numbers was not only emerging, but weaving itself into the fabric of accepted conduct ... A gamesmanship that let[s] small, but obvious and important discrepancies slide; ... [and] that focuses exclusively on short-term numbers rather than long-term performance ...' (Levitt, 1999). The argument is borne out by evidence which reveals that the number of entities that have crossed from 'legitimate' to 'illegitimate' reporting has grown in frequency and size in the recent past. Floyd (2003: 5-7) has observed a 150 per cent increase in the number of restatements in the US due to accounting irregularities between 1996 and 2002. Over the same period, the median size of US companies making restatements as measured by market capitalisation has increased from $\$ 500$ million to $\$ 2$ billion.

This evidence aside, the above arguments are all suggestive of errors in accounting numbers due to variable practices in the application of accounting principles. On this score, then, it is significant that efforts are underway to ensure convergence in global accounting practice. South Africa, for instance, already conforms to global accounting standards, and the European Union, a number of Asian countries and Australia are committed to harmonising their standards with global practice by 2005 . Moreover, the US's FASB and the International Accounting Standards Board are currently engaged in a convergence project. However, even if perfect harmonisation of accounting practice is achieved internationally, problems in practice still exist. Three observations are made in this regard.

First, extant loopholes in legislation facilitate concealment of information by management (Fouche \& Van Rensburg, 1999). Furthermore, even if full disclosure took place, problems occur with monetary expression. Not all transactions, obligations or rights can be easily reduced to a single figure. Also, changes in macroeconomic variables - such as foreign exchange rates and price inflation are not necessarily reflected in accounting data. In these circumstances, even the most consistent application of traditional accounting methods can result in significant misstatement of figures. What is more, factors such as taxation asymmetries, transactions costs, agency costs, risk hedging, asset liquidity and legislative differences can affect the relevance of accounting data (Correia et al, 2000). A last point in this regard is raised by Staley (1997), who reports on various accounting anomalies, including examples where columns of numbers that do not add up are reflected in accounting statements. ${ }^{13}$ In this regard, solutions available to the financial analyst in dealing with these sources of anomalies often lie beyond accounting practice as they rather embrace the development of improved valuation models, better measurement techniques and enhanced understanding of legal and fiscal environments. For this reason, the treatment of anomalies identified under this first point is left for discussion elsewhere.

Second, ridding accounting practice of all inconsistencies will not eradicate the human practice of accounting fraud. Unfortunately, numerous examples of fraudulent reporting exist internationally, as well as domestically. On this score, two solutions present themselves. To start with, it is possible to discourage fraudulent behaviour by increasing financial and social sanctions. Next, and in any event, the analyst should devote some resource to verifying the legality of data. In this regard, and as an aside, an easily applied mathematical principle emerges as a heuristic device in the detection of accounting irregularities - particularly 
accounting fraud. The principle, Benford's Law (Paulos, 2003: 72-74), states that in a wide variety of circumstances, numbers - as diverse as the drainage areas of rivers, populations of small towns and half-lives of radioactive atoms - have ' 1 ' as their first non-zero digit disproportionately often. Specifically, random collections of random numbers begin with ' 1 ' 30.1 per cent of the time, ' 2 ' about 17.6 per cent of the time, ' 3 ' 12.5 per cent of the time and larger digits progressively less often. ${ }^{14}$ For instance, only 4.5 per cent of the numbers in these cases begin with the digit '9'. However, when people attempt to fake plausible-seeming numbers, they generally violate Benford's Law. For this reason, Benford's Law has become a convenient tool for quickly interrogating numbers for potential fraud (via, for example, account manipulation). Of course, whilst using the law to detect fraud may improve detection, increasingly sophisticated frauds could rely on the generation of 'fraudulent but compliant' data that would act as a countervailing force in the detection of fraud or error.

Finally, and most critically, in some vital places accounting practice fails to recognise economic realities. The most important examples of this include the partial treatment of capital costs (see Section 4.1) and flawed treatment of depreciation (see Section 4.4). Yet, much can be done to bring accounting practice closer into line with economic reality. Accordingly, the remainder of this paper is devoted to examining central arguments in this regard, which are presented below in Section 4.

As noted, then, sources of error in accounting data are numerous and varied. In many instances, sources of data error may be diminished by the convergence that is underway in global accounting practices. Nevertheless, the rate of convergence is sufficiently slow to argue that error sources will persist in the foreseeable future. Moreover, even under convergence, sources of error remain. Indeed, in drilling down to the most basic level of financial analysis, the level of data inputs, it becomes apparent that even the most robust models and reliable forecasting tools are worthless when based upon accounting data that has the propensity to vary significantly in reliability, accuracy and continuity. Accordingly, given the paper's focus on 'stage one' error, and against the backdrop of sources of error identified above, Section 4 turns to examine primary sources of accounting data error, where the emphasis of the examination is placed on the discovery of tools for redressing these errors.

\section{4 A Way Forward}

It is unrealistic to expect the sources of error extant in accounting data to be effectively eliminated by the stroke of a pen. Rather, pragmatism suggests that eliminating the sources of accounting error should first involve identifying and addressing major sources of error. Necessarily, this identification process is based on a subjective ranking of the sources of error. Nevertheless, using careful analysis of anecdotal evidence, and adapting from Stewart (2002), a list of five 'primary' errors relevant to the South African environment is set out below. As an aside, it goes without saying that in order for any of the 'fixes' that are identified to be effective, it is necessary that a 'tone' of accurate, reliable and responsible reporting be set at the top of firms. Returning to the argument, a brief explanation of each item identified is provided, and solutions to current problems in practice are offered below in this section.

The primary items adopted from Stewart's (2002: 3) list include: conversion of accounting profit into economic profit figures; treatment of pension fund positions such that surpluses (deficits) are brought onto balance sheets and taken out of income statements; elimination of the use of 'cookie jar' reserves to manage earnings; moving away from the mechanical treatment of depreciation; and expensing of stock options.

In proceeding, it should be recognised that the extent to which each problem impacts on the reliability of accounting data varies across companies, industries, countries and by year. However, using global as well as domestic evidence, the list is argued to contain items that have the propensity to play significant roles in influencing the validity of accounting data in South Africa (and elsewhere in the world). 


\subsection{Conversion of accounting profit into economic profit}

For accounting figures to accurately represent the profitability of a business, it is necessary that the data bear the full weight of the cost of capital. Yet, universally, accounting figures are prepared on a partial cost of capital basis. The cost of equity is not accounted for in firms' income statements. Indeed, failing to recognise that shareholders, as well as lenders of capital, expect and deserve to earn a fair return on their investments is by far the most insidious source of accounting overstatement. Fully costing capital calls for accountants to measure and report 'economic profit'. As Stewart (2002: 1) puts it, 'this is the way ... smart investors keep score'. In this vein, Partnoy (in Stewart, 2002: 2) notes: 'Reported earnings follow the rule and principles of accounting ... [But] ... The results do not always create measures consistent with underlying economics'. Moreover, if one recognises the practical importance of reported earnings, then it is critical to get accountants to produce figures that are more accurate and reliable than those being generated under current rules. Thus, although accountants subtract interest expenses associated with debt financing, they do not place any value (cost) on the funds that shareholders have put into or left in a business. As such, accountants consider equity capital a free resource. This oversight means that companies often report accounting profits when they are destroying shareholder value. Economic profit eliminates this glaring distortion by subtracting from income the cost of all capital used to generate revenues, including the cost of equity capital (Stewart, 2002: 4)..$^{15}$

Importantly, the difference between accounting profit and economic profit is considerable. ${ }^{16}$ For instance, the book capital of the largest 1000 firms in the US is US\$2.9 trillion. If equity is costed at a rate of 10.0 per cent per annum, the aggregate profit of the 1000 firms reported for 2001 falls from US $\$ 96.0$ billion to a loss of US\$194.0 billion (Stewart, 2002: 5). In the case of South Africa, based on analysis of a group of 150 large-, midand small capitalisation companies listed on the JSE Securities Exchange (JSE), aggregate accounting profit in 2002 amounted to R119.4 billion. However, subtracting a cost of equity charge from income - levied at a rate of 15.0 per cent of the total value of equity capital per annum - aggregate net income declines by 74.3 per cent to R30.6 billion. ${ }^{17}$ This outcome demands a further note. In a world where investment opportunities are arbitraged away, one would expect economic profits to fall to zero. Thus, the fact that accounting profits decline once measured as economic profits should come as no surprise - any elementary economics textbook illustrates this argument. What is surprising is that the figures are generally not considered in investment analysis. Also, the high negative number in the case of the US market suggests materially skewed (inefficient) capital allocations.

Detail aside, converting accounting profits into economic profits has immediate - and dramatic - implications for valuing firms and assessing investment performance. Moreover, the argument holds at the level of the firm (stock-specific valuation) as well as the level of the market (asset-class valuation). Importantly, the bookkeeping change needed to fix this flaw in accounting is elementary. Earnings incur a debit for the cost of equity, and the same figure is added back by crediting book equity. The entry leaves the balance sheet and cash flow statement unaffected, but brings net income in line with economic profit. Further, whilst the cost of equity may not be measured precisely, any systematic measurement technique that conforms to modern finance theory will significantly improve upon current estimates of firms' profits (Stewart, 2002: 5).

\subsection{Pension fund accounting}

A second key source of accounting error involves the treatment of pension funds and, in particular, defined-benefit funds. The root of the problem is that accountants do not treat pension accounts as true corporate liabilities and assets. Yet, whether paid out of cash flow of a going concern, or out of the cash pool of a bankrupt entity, a firm's pension liability is its most senior debt. Similarly, a firm's pension 
fund assets are first tier corporate assets because they directly offset the firm's pension liability. As such, the pension fund position arguably should appear as the first line in the balance sheet. However, accountants tend to misrepresent the true nature of pension assets and liabilities by only disclosing them in offbalance sheet notes. Moreover, accountants ignore or smooth risk, and so systematically understate the expense of paying for a pension plan (Stewart, 2002: 10-14). On this point, accountants tend to discount future pension liabilities at a rate of return expected from pension fund assets - that rate reflects the risk of return from those assets. But, the correct rate to discount the pension liability is the yield offered by a portfolio of bonds (or other low risk instruments) that is one credit rating notch higher than the credit rating of the firm itself, because the pension liability is senior to a firm's most senior lenders. Again, however, accountants tend not to follow this course, and rather assume discount rates that reflect the firm's overall cost of capital (Stewart, 2002: 1014). In turn, this figure reflects the firm's risk of return from business operations - which confuses financial and operating decisions. Alternatively, accountants assume a discount rate that echoes the expected rate of return from pension fund assets, which is an equally inappropriate blend of higher risk equities and lower risk bonds.

Considering the evidence, treatment of current pension accounting rules in the US remains an important tool in managing firms' earnings. US companies can report expected financial gains from pension investments, even when they suffer operating losses, as a way of reducing earnings volatility. For example, a recent study points out that nine large US companies turned US $\$ 30.6$ billion of pension fund losses in 2002 into earnings before taxation of US\$7.9 billion. If actual pension losses had been counted in financial statements, 2001 earnings for the S\&P 500 companies would have been 69 per cent lower than reported. Further, one of the most obvious ways in which to manage earnings from pension funds is to adjust assumptions about future rates of return. In the case of companies contained in the
S\&P 500 index, raising forecast returns by 100 basis points translates into pension fund benefits of US\$5.0 billion (Institute for Global Ethics, 2003).

In the case of South African firms, the past two decades have seen pension funds increasingly shift from defined-benefit to defined-contribution plans (Andrews, 2002: 2$3)$. The implication is that the scope for accounting irregularities under definedcontribution plans is significantly diminished. Nevertheless, three points demand recognition. First, there are a number of high profile examples of accounting irregularities that stem from misreporting of pension fund positions in South Africa, with the highest incidence arising in the case of defined-benefit funds. In the late 1990s, for instance, a R200 million hole was discovered in the pension fund of the state-owned forestry business, Safcol. Large fund deficits have also been discovered in other state-owned enterprises, including Telkom and Transnet. In the latter case, government made a payment of R1.3 billion in 1999-2000 to meet a shortfall in the Transnet Pension fund attributable to South African Airways' pension commitments. Second, accounting irregularities in the case of pension funds are not confined to the public sector, with a number of private-sector cases existing. The recent collapse of JSE-listed technology company, for instance, revealed a pension fund deficit that the firm's accountants had previously not publicly reported. Third, the migration of pension funds from definedbenefit to define-contribution plans has left many defined-benefit plans closed, but firms' exposure and commitments to members of defined-benefit plans remains. Put simply, closure of a fund to new members does not extinguish the claim of old members on the fund and, so, the firm. Accounting practice, however, has tended to brush over this fact. ${ }^{18}$

In short, the growing prevalence of definedcontribution plans amongst South African firms has reduced the scope for abuse of pension fund positions in financial reporting. Nevertheless, possibilities for accounting error or fraud remain, particularly in the case of definedbenefit plans. Upon closer scrutiny, then, the correct treatment of pension fund positions is 
to put pension assets and liabilities on the balance sheet, and to record the service cost as the true pension cost on the income statement. Further to this, if firms continue to take investment gambles in their pension funds, then the outcomes of these gambles should be recorded as a line item reflecting actual unsmoothed speculative gains or losses in the income statement (Stewart, 2002: 14). In the case of South African firms, it is suggested that treatment of these positions could be as per accounting statement AC133.

\subsection{Elimination of the use of 'cookie jar' reserves}

A third means by which accountants manage earnings is by using earnings reserves, where losses from bad loans and receivables are anticipated and transferred to a 'bad debt' reserve (Stewart, 2002: 16). These so-called 'cookie jar' reserves are used up as receivables 'go bad', and are replenished by a charge to earnings each year known as provisions. However, whilst the theory is clear-cut, practice is murkier. In flush years, for instance, accountants are tempted to bump up provisions (such as provisions for bad debts) to hoard earnings so that in poor years over-estimated losses can be written back from the balance sheet. In a similar fashion, deferred taxation represents a 'cookie jar' reserve that can be used by companies to write earnings back to the income statement in unfortunate years. In either event, reserves provide a ready device for managing earnings. The vehicle is also a means whereby highly cyclical firms can dampen reported earnings volatility which, in turn, may improve analysts' ratings of the firm and its managers. Yet, any such improvement would be based on cosmetic changes, rather than substance.

Examples of this type of procedure are apparent across all industries, although cyclical industries are more prone to the practice. Considering the South African situation, as at December 2002, the forty largest companies listed on the JSE, as measured by market capitalisation, had a combined income of R76.7 billion. At the same time, however, the aggregate balance sheet reflected deferred taxation liabilities - which could be written back into the income statement - of R35.9 billion. In other words, the companies had an aggregate pre-taxation income reserve equivalent to six months of after taxation earnings - a ready arsenal for smoothing income. Moreover, the figure does not include other income smoothing vehicles, such as provisions for bad debt. In this regard, anecdotal evidence exists of the use of earnings smoothing by South African-listed companies to manage earnings and meet analysts' expectations. The banking industry, where provisioning is commonplace, provides a useful case in point. Specifically, for their 2003 year ends, the five largest banking groups in South Africa carried aggregate provisions for bad debt of R13 643.2 million on their balance sheets. At the same time, collective annual income attributable to shareholders for the same year ends amounted to R15 041.3 million. ${ }^{19}$

The antidote to excessive conservatism being used to manage earnings is to subtract from net operating profit after taxation (NOPAT) the actual charge of the bad debts as they occur and not in advance, and to record loans and receivables at face value without the subtraction of any reserve. That done, if a credit goes bad the write-off is charged directly to earnings instead of being routed through the reserve account. This makes accounting simpler, and magnifies the incentive of managers to respond to bad debts by more diligently seeking recovery and being more careful about extending credit (Stewart, 2002: 16). This new practice would also elevate economic substance over cosmetic appearance.

\subsection{Straight-line depreciation}

A fourth primary error source is the manner in which accountants treat depreciation. As Stewart (2002: 25) notes, it is arithmetically impossible to measure a business's accounting profit steadily and its true rate of return using the same depreciation schedule. Accountants have elected to use depreciation schedules that measure operating profit steadily. However, that decision renders financial statements less useful 
to the fundamental valuation of any business (although it is most pronounced in the case of heavy investments made in long-lived physical assets).

Depreciation stems from the orderly liquidation of an investment in an asset as the asset is 'consumed' over its productive life. However, because the end value and terminal date of an investment cannot be known in advance, the depreciation schedules used by accountants necessarily are arbitrary, and usually assume that assets depreciate in value in a straight line with time. As already noted, the practice is useful to accountants in that it tends to stabilise the measurement of reported profit (Stewart, 2002: 25). Yet 'straight-line' depreciation invariably distorts a firm's rate of return and economic value added. With straightline depreciation, the measures are understated after a new asset is first added, and overstated as the asset is depreciated over time. This creates a perverse incentive for managers to avoid adding new assets, and to retain older assets beyond their optimal productive age. Again, then, we have a seemingly innocuous bookkeeping practice becoming a serious impediment to economic efficiency and maximisation of shareholder value.

Given this outcome, some firms have recognised that straight-line depreciation creates an accounting perversion. As a consequence, many of these firms - especially those in 'asset heavy' industries - have attempted to replace earnings before interest, taxation, depreciation and amortisation (EBITDA) for GAAP earnings. However, whilst the diagnosis is correct, the remedy is drastic. Although depreciation is not a cash cost, it is a legitimate charge to earnings. Thus, the answer is not to abandon profit and embrace cash flow, but to compute profit with economic depreciation in place of book depreciation. The key to accurate measurement, however, lies in recognising that economic depreciation does not generally follow a straight-line pattern. Rather, depreciation typically grows larger each period as an asset ages and approaches the point at which it needs to be replaced. Based on this, Stewart (2002: 25-26) argues that the solution entails replacing straight-line depreciation with a capital charge based on total cost of asset ownership (TCO). ${ }^{20}$ To illustrate the argument, take an asset worth R10.0 million with a required rate of return of 10.0 per cent per annum. In this example, a payment of R1 627454 per annum over ten years has a present value of R10.0 million. From this figure, if one deducts the cost of capital (say, 10.0 per cent per annum on the total asset value) the remaining figure is the cost of depreciation. Table 1 illustrates the depreciation cost cycle over the life of the asset. The example can be further illustrated by assuming that the asset yields an annual return of R1.8 million. From this, the net operating profit after tax (not shown) and return on asset (ROA) figures can be calculated. The numbers are set out in the table below.

Table 1

Economic depreciation calculation

\begin{tabular}{|c|c|c|c|c|c|c|}
\hline Year & $\begin{array}{c}\text { TCO } \\
\text { (Rand) }\end{array}$ & $\begin{array}{c}\text { Cost of } \\
\text { capital (Rand) }\end{array}$ & $\begin{array}{c}\text { Depreciation } \\
\text { (Rand) }\end{array}$ & $\begin{array}{c}\text { Start capital } \\
\text { (Rand) }\end{array}$ & $\begin{array}{c}\text { End capital } \\
\text { (Rand) }\end{array}$ & ROA (\%) \\
\hline 1 & $1,627,454$ & $1,000,000$ & 627,454 & $10,000,000$ & $9,372,546$ & 11.73 \\
\hline 2 & $1,627,454$ & 937,255 & 690,199 & $9,372,546$ & $8,682,347$ & 11.84 \\
\hline 3 & $1,627,454$ & 868,235 & 759,219 & $8,682,347$ & $7,923,127$ & 11.99 \\
\hline 4 & $1,627,454$ & 792,313 & 835,141 & $7,923,127$ & $7,087,986$ & 12.18 \\
\hline 5 & $1,627,454$ & 708,799 & 918,655 & $7,087,986$ & $6,169,331$ & 12.43 \\
\hline 6 & $1,627,454$ & 616,933 & $1,010,521$ & $6,169,331$ & $5,158,810$ & 12.80 \\
\hline 7 & $1,627,454$ & 515,881 & $1,111,573$ & $5,158,810$ & $4,047,237$ & 13.34 \\
\hline 8 & $1,627,454$ & 404,724 & $1,222,730$ & $4,047,237$ & $2,824,506$ & 14.26 \\
\hline 9 & $1,627,454$ & 282,451 & $1,345,003$ & $2,824,506$ & $1,479,503$ & 16.11 \\
\hline 10 & $1,627,454$ & 147,950 & $1,479,504$ & $1,479,504$ & 0 & 21.66 \\
\hline
\end{tabular}


In considering Table 1, four points bear noting (Stewart, 2002: 25-28). First, by assuming a hurdle rate of return on the asset (10.0 per cent per annum) over the lifespan (ten years) of the asset, it is possible to generate a net asset value figure that accurately reflects the total cost of owning the asset. The numbers are set out in column two of Table 1 under the heading 'TCO'. Second, the TCO is made up of two components: (i) a cost of capital based on the funding requirement; and (ii) a depreciation cost attributable to usage. The first cost is based on the cost of funding rate and the capital employed - assumed to be 10.0 per cent per annum and R10.0 million at the start date. From this figure, and the TCO figure, it is possible to impute a depreciation charge. If we assumed a straight-line depreciation rule, the depreciation cost would amount to R1.0 million per annum. The economic depreciation charge, however, escalates as the asset approaches exhaustion. This is a far more meaningful reflection of economic reality than the straight-line bookkeeping basis. Third, due to the more accurate depreciation figures, NOPAT declines more aggressively as depreciation charges escalate at an increasing rate with time. Fourth, ROA also climbs as steady economic value (R1.8 million per annum) is added to a shrinking asset base. In the final analysis, the economic method of depreciation provides a far more meaningful and reliable basis for accounting for assets and asset returns over time. ${ }^{21}$

\subsection{Stock options are an expense $\mathrm{e}^{22}$}

Stock options used to remunerate employees are a form of compensation that should be expensed as exercise rights vest with employees. However, many firms fail to expense stock options. This represents a fifth principal source of accounting error. In this regard, the maltreatment of options in accounting is the result of two steps in the issuing of the instruments being collapsed into a single step. An employee option grant is substantively the same as compensating the employee with cash - which is obviously an operating expense and then compelling the employee to use the cash to purchase an option from the business at its fair market value - which is a separate investment decision (Stewart, 2002: 28). Thus, whether the option is eventually exercised or allowed to lapse has nothing to do with the cost to company of granting the option. The true cost of the option is given by the option's fair economic value at the date of grant. Once the option is outstanding, the costs or benefits of exercise are for the holder of the option, and have no bearing on corporate expenses or the income statement. Nevertheless, companies have been reporting information on stock options in the notes to their financial reports for some time. Moreover, corporate managers often mistakenly think of options as an inexpensive way to compensate and motivate managers and employees.

Recently, some firms have started to move towards recognising the cost to company of option grants. Beverages firm Coca Cola provides one of the best known cases in point. Further, some firms have started to move away from the use of option grants altogether. Microsoft is one such entity. Nevertheless, many firms continue with the practice of treating the granting of options as a costless exercise. This practice is patently flawed. If a firm is to accurately present its financial activities and commitments, then options are to be expensed under employee compensation, and earnings are to be diluted to reflect the effect of vested options. Anything short of this is tantamount to inflating earnings.

Turning to practice to illustrate the financial impacts under this point, technology stocks have become renowned for their use of options to attract and retain staff. However, they have become equally well-known for their opaque accounting treatment of options. On this score, a study conducted in 1999 estimates that earnings of technology counters listed in the S\&P 500 would decline by approximately 20 per cent if vested options were included in the earnings per share calculations. ${ }^{23}$ For the broader market, the impact of options on earnings is somewhat less powerful than in the case of technology counters. Nevertheless, the effects remain meaningful. A recent study by Bear Stearns and Company found that if stock 
options were taken into account, aggregate earnings per share for the S\&P 500 in 2000 would have fallen by about 9 per cent. Interestingly, at the time the study was undertaken, only two S\&P 500 companies, Boeing and Winn-Dixie, reported earnings after expensing options.

Considering the case of South African firms, unfortunately no overall estimate for the effects of options on reported earnings of listed companies exists. However, as is the case in the US, extant general accounting practice is not to expense options. Yet, anecdotal evidence suggests that the impact of options on earnings is meaningful. Two diverse examples serve to illustrate the effect of options on earnings. In the case of the short-term insurance sector, it is found that options result in dilution of reported headline earnings per share of between 0.7 per cent and 4.8 per cent, based on 2002 annual financial results. The average across the sector is 2.7 per cent dilution of headline earning per share.

The effect of vested options on headline earnings is somewhat more potent in the case of the information technology sector. Data on the ten largest listed technology stocks, which account for 89.3 per cent of the sector's market capitalisation as at end July 2003, reveal that average dilution of headline earnings per share due to vesting options stood at 7.6 per cent for the most recent financial years. ${ }^{24}$ The higher dilution is in line with international trends, although the absolute level sits somewhat lower than the US case (as reported above).

In short, options impact on companies' financial statements, with the effect varying across firms and industries. For this reason, it is essential that the effect of options be incorporated into the analysis of firms' financial positions. Here, two points demand emphasis. First, options are not always expensed. This under-reporting requires urgent rectification. Yet, and second, even where options are expensed, the accounting treatment is complex. The reason for this is that valuing options is a thorny task. By way of example, Damodoran (2002) sets out four different ways in which options can be treated in accounting practice, and a wide range of models can be employed in valuing options (Hull, 2002). In turn, the variation in treatment and valuation produces a wide range of feasible accounting cost inputs.

From this, two suggestions are made with regard to the accounting treatment of options. First, where options are used by firms as a basis for remuneration, it is important that options be fully costed once vested. ${ }^{25}$ However, because of the complexity encountered in valuing options, it is suggested that the practice be treated with particular watchfulness. Nevertheless, complexity in valuation is not a basis for abandonment of valuation in accounting practice. Accordingly, and second, given the difficulty encountered in costing options, it is suggested that firms consider the use of shares to replace options on shares in remuneration. The attraction of this approach is that simplicity and transparency substitute for the opaque vehicle of remuneration using options. In this vein, McNulty (2003) notes: 'Options are financial instruments [that] are difficult to value for accounting purposes, regardless of the share price, even if they are assessed as costs. Ordinary shares carry the virtues of simplicity and transparency'. In either instance, however, it is unambiguously clear that the issuing of shares, or options on shares, is not a costless form of compensation. In recognising and correctly accounting for this outcome, firms have the opportunity to reevaluate the effectiveness of incentive schemes based on share options (or shares) against other incentive plans, including cash bonus plans that attempt to simulate incentives by sharing the economic rewards and risks of firm ownership. The net result of the shift in accounting treatment, however, will be more transparent and more reliable accounting outcomes. Significantly, with effect from 2005, South African accounting principles require firms to expense options issued to employees.

\section{5}

\section{Conclusion}

Financial analysts place substantial weight on accounting data drawn from firms' financial statements in investment analysis. However, 
recently, unease over the usefulness of accounting data in financial analysis has mounted as a growing number of accounting frauds, malpractices and manipulations have materialised. Moreover, evidence suggests that the incidence of accounting malpractice, fraud and manipulation has grown in terms of size over the past five years. These trends are of great concern for parties that are interested in the financial status of the firm - not least of all financial analysts. In turn, concern amongst financial analysts has two main thrusts. First, investors - the clients of financial analysts have incurred substantial losses through wrongly-placed confidence in some accounting data. Second, and in many ways as a consequence of the first outcome, illegitimate practices, such as fraud and misreporting, as well as 'legitimate' manipulation of accounting data have brought into question the usefulness of accounting data in financial analysis. Unfortunately, the issue of accounting data reliability has been complicated further by the increased blurring of the line between legitimate and illegitimate practices.

In any event, as a consequence of the above forces and influences, concern amongst financial analysts over accounting practice has intensified. As such, if accounting data are to reassume their rightful place in financial analysis, then it is time that accounting practices underwent a meaningful overhaul: it is time to get accountants to start counting what counts.

There is a host of widely varying potential error sources in accounting data. But, as a point of departure, this paper identifies five main sources of error, namely the practice of partially costing capital; the inappropriate handling of pension plan funds; the use of 'cookie jar' reserves to manage earnings; the mechanical treatment of depreciation that ignores basic economic principles; and the practice of ignoring share options as a cost in employee compensation and a diluting influence in the calculation of per share data. Based on the evidence presented, it is apparent that the distortions caused by these practices are considerable; and the South African accounting environment is no exception. For instance, research conducted in this paper reveals that shifting to full cost of capital accounting would have resulted in earnings reported by a group of 150 companies listed on the JSE falling by almost three-quarters in recent financial years. Similarly, research suggests that share options potentially have a meaningful deflationary effect on reported earnings amongst listed firms - although the effect seems to vary widely across firms and industries. Some South African firms also are found to hold substantial 'cookie jar' reserves as a tool that can be applied in the management of firms' earnings. Moreover, the arguments and evidence presented suggest that South African firms' generally inadequate treatment of depreciation and sometimes inappropriate method of handling pension funds are likely to heavily distort accounting data.

Yet, through a series of corrective measures, each of the practices identified is readily righted. In turn, these measures would serve as a platform for undoing misreporting and, more importantly, taking accounting data back into the realm where the numbers presented in financial statements are not only perceived as being useful by the financial analyst but, as a point in fact, become valuable to the analyst. Moreover, other benefits would flow from these corrective measures. For instance, more reliable accounting data would provide a platform for improved financial forecasting. More reliable data also would help in improving the models engaged by analysts in appraising investments and investment strategies.

However, this is not the end of the story. As noted, other sources of accounting data error exist. But, in order to move towards an environment wherein reliable and useful accounting data are generated, it is necessary to take the first steps. The argument in this paper is that elimination of the five primary error sources identified would constitute such a step. Failure to do so will maintain the status quo: an accounting environment where the transparency, trust, independence and authority needed to make the accounting system work are in great demand, but short supply.

In short, a small number of highly effective improvements to accounting practices have the propensity to shift accounting numbers into a 
setting wherein the data more accurately reflect the economic realities of firms and are of real use in financial analysis. In the same breath, failure to correct accounting principles and practices will leave analyst working with financial information that ranges from misleading to patently false. Then again, in the absence of such improvements, analysts can always revert to devices, such as Benford's Law, which in many instances have proven to be more reliable than accounting data in sorting reality from fiction. This outcome, however, would be a second-rate conclusion.

\section{Endnotes}

1 The author would like to thank Eustace Davie, Kerry Hadfield, Barry King, Warwick Lucas, Henry Mkize and David Oakes as well as two anonymous referees for contributions made to this paper. However, the usual riders apply, with all errors and omissions the sole responsibility of the author.

2 International examples embrace a diverse set of high-profile companies such as Enron, WorldCom, Lucent, Adelphia, Ahold, Tyco, Intel, Yahoo, AOL-Time Warner and Global Crossing (Paulos, 2003). Similarly, the South African business environment is scattered with a diverse range of examples.

3 D'Agostino and Williams (2002) identify 919 cases of accounting restatements made by listed companies between 1 January 1997 and 30 June 2002 which resulted in adjusted immediate losses in market capitalisation of US\$100 billion.

4 This fifth application of accounting data relies on aggregated data, whereas the other tasks all rely upon firm-specific data.

5 Not all researchers agree with the argument that analysts' forecasts are biased. Lim (2001), for example, presents arguments which suggest that 'inaccurate' is not necessarily synonymous with 'irrational'.

6 The literature on model misspecification is extensive, and a discussion of the topic is beyond the scope of this paper. However, for an introduction to the literature, see Friedman (2002).

7 This argument could explain the result reported by Warwick (2000: 64) that forecasters using computer models do no better than those relying solely on their subjective judgment, and those using large models of over a thousand equations fare no better than those using simpler models of only a few equations.

8 As an aside to this point, it has been commented that if accounting data were more accurate then models, such as the CAPM, might deliver more consistent results (Pers. comm., Warwick Lucas).

9 See Floyd (2003) for evidence of the growing incidence of accounting fraud.

10 For example, networking firm Cisco used pooling to avoid paying US\$6.8 billion goodwill in its US\$6.9 billion purchase of Cerent. That aside, as noted by David Oakes, pers. comm., accounting rules change with time, and the accounting practice referred to in this note is no longer possible under current accounting rules. Moreover, these rules are expected to change again shortly.

11 The dot.com boom of the late 1990s offers numerous examples of revenue overstatement, such as the practice of reporting 'barter of Internet advertising' as revenue. However, examples of revenue manipulation extend beyond the Internet arena. For instance, using a complicated accounting principle known in corporate finance circles as 'prepay', Enron was able to record the proceeds of debt issuance as revenue of US $\$ 9.0$ billion.

12 Stock options represent the most obvious case in point, with the Financial Accounting Standards Board (FASB) in the US having responded slowly to the appropriate treatment of these financial instruments in practice. The accounting practices of dot.com businesses offer the best examples of the diluting effects of options. For instance, Kelly (1999) notes that, in 1998, 
Yahoo was one of the world's few Internet companies that reported profits. However, if options issued to directors were expensed, the earnings figure converted to a loss equal to one-half of the reported profits.

13 Listed company Synergy Holdings (Pty) Ltd offers an example of a South African company releasing figures that do not add up when, for the full year to end February 2003, the company released incorrectly stated gross revenue figures.

14 The 'power law' is explained by the effects of compound growth.

15 The cost of equity is not a cash cost, but an opportunity cost. It is the return that a firm's shareholders can expect to earn in an alternative investment. Thus, the cost of equity is the cut off rate required to create capital value in a firm.

16 In this calculation, assumptions need to be made about the cost of equity. This is a topic of intense academic debate and substantial empirical research. For a review of the issues, see Warwick (2000).

17 To account for the cost of equity at the headline earnings level, a cost based on the risk free rate of interest and the equity premium needs to be charged to the firm's equity. For the sake of the example, a figure equal to 15 per cent per annum is levied. Whilst the exercise is simplistic in terms of the rate used, the quantum effect is sufficient to suggest that a full cost of capital charge is material in its financial impact. It should be noted, however, that the cost of capital is expected to fluctuate with time as the risk free rate of interest and the equity premium adjust to reflect different economic realities.

18 See Andrew (2002) for a review of the valuation issues and accounting implications of closure and treatment of surpluses and deficits of defined-benefit funds.

19 Data drawn from various annual financial reports for the 2002 and 2003 financial years. Admittedly, legislation historically has allowed banks to make greater provisions that provided for under the Companies Act of 1973 (Pers. comm., Barry King).

20 The practice is equivalent to removing the asset from the firm's balance sheet (sale) and introducing a charge for use of the asset (lease-back). When viewed in this context, it becomes more apparent that the practice of straight-line depreciation is flawed: what chief executive officer would agree to a lease-back agreement that loads upfront rentals to allow for a steadily declining charge with time?

21 Alternatives to this approach to depreciation exist. For instance, depreciation could be expensed on the basis of productivity, which would entail measuring maintenance costs as well as lost productive potential that occur with time.

22 No comment is made in this section on convertible debentures which also are frequently used to incentivise employees. However, principles similar to those arising in the case of stock options materialise in the instance of convertible debentures.

23 Note that the calculations carried out in this section, to illustrate the two examples, only measure the difference between undiluted and diluted headline earnings per share caused by the number of vesting options. The calculations do not measure the cost to company of issuing options. This second calculation is a complex exercise (Damodoran, 2002) and indeed, justifies a separate investigation in its own right.

24 Sourced from http://www.resultsdata.co.za.

25 Here, however, a different problem emerges. If reported on a fully diluted basis, options still can be 'used' to manage earnings per share figures. For instance, canceling 'artificially created' options would be one way of inflating earnings.

\section{References}

1 ANDREWS, J.P. (2002) "Conversion from defined benefit to defined contribution", Paper presented to the International Actuaries Association, Brighton, England. 
2 ARNOLD, J. \& MOIZER, P. (1984) "A survey of the methods used by UK investment analysts to appraise investments in ordinary shares", Accounting and Business Research, Summer: 195-207.

3 ARNOLD, J., MOIZER, P. \& NOREEN, E. (1984) "Investment appraisal methods of financial analysts: a comparative survey of US and UK practices", Paper presented at the European Accounting Association Convention, Switzerland.

4 ARNOTT, R.D. (2001) "Implications for asset allocation, portfolio management, and future research I", Equity Risk Premium Forum, November 2001.

5 CLACKWORTHY, S. (2000) "The value of reporting”, Management Accounting, March: 3839.

6 CONRAD, B. \& SALAMIE, D. (2002) "Asset allocation strategies and their effect on risk and return from 1996 to 2000", Journal of Financial Planning, March (7): 1-10.

7 CORREIA, C., FLYNN, D., ULIANA, E. \& WORMALD, M. (2000) Financial Management ( $4^{\text {th }}$ ed.) Juta: Cape Town.

8 CRUMBLEY, D.L. \& APOSTOLOU, N.G. (2002) "Stock option accounting can be materially misleading", Journal of Forensic Accounting, 3: 131-38.

9 D'AGOSTINO, D.M. \& WILLIAMS, O.M. (2002) "Financial statement restatements", Report to the Chairman, Committee on Banking, Housing, and Urban Affairs, United States General Accounting Office: Washington.

10 DAMODORAN, A. (2002) "Management options and value per share", Working paper, Stern School of Business: New York.

11 FLOYD, J.J (2003) An Analysis of Restatement Matters: Rules, Errors, Ethics for the Five Years Ended December 31, 2002. Huron Consulting Group: Chicago.

12 FOUCHE, S. \& VAN RENSBURG, P. (1999) "A survey of the investment appraisal techniques used by South African unit trust portfolio managers", Investment Analysts Journal, 49(2).

13 FRIEDMAN, C. (2002) "Confronting model misspecification in finance: Tractable collections of scenario probability measures for robust financial optimization problems", International Journal of Theoretical and Applied Finance, 5(1): 33-54.
14 GRIFFITHS, A. AND WALL, S. (2001) Applied Economics, London: Prentice Hall.

15 HULL, J.C. (2002) Options, Futures and Other Derivatives, ( $5^{\text {th }}$ ed.) London: Prentice Hall.

16 IBOTTSON, R.G. AND KAPLAN, P.D. (2000) "Does asset allocation policy explain 40, 90, or 100 per cent of performance?", Financial Analysts Journal, 56(3): 26-33.

17 INSTITUTE FOR GLOBAL ETHICS (2003) "Use of accounting rules to erase pension fund losses”, Ethics Newsline, 6(12): 1.

18 KELLY, H. (1999) "The earnings your mother didn't tell you about”, Stock Analysts Journal, 3 March 1999.

19 KIESO, D.W. \& WEYGANDT, J.J. (1982) Intermediate Accounting, Canadian Edition, Toronto, Canada: John Wiley \& Sons.

20 LEVITT, A. (1999) “The "numbers game", Paper presented to the NYU Center for Law and Business, New York, September 28, 1999.

21 LIM, T. (2001) "Rationality and analysts' forecast bias", Journal of Finance, 56(1): 369-85.

22 MCNULTY, A. (2003) "New thinking on options", Financial Mail, 172(4).

23 MULFORD, C.W. \& COMISKEY, E.E. (2002)

The Financial Numbers Game: Detecting Creative Accounting Practices, John Wiley \& Sons: Chichester, England.

24 PAUlOS, J.A. (2003) A Mathematician Plays the Market, Allen Lane: London.

25 PEASNELL, K.; POPE, P. \& YOUNG, S. (2000) "Detecting earnings management using cross-sectional abnormal accruals models", Accounting and Business Research, 30(4): 31326.

26 STAINBANK, L.J. (2003) "Perceptions of preparers and users on the usefulness of financial statements", Paper presented to the Annual Conference of the KwaZulu-Natal Branch of the South African Accounting Association, 13 June 2003, Durban.

27 STALEY, K.F. (1997) The Art of Short Selling, John Wiley: Chichister, England.

28 Stewart, G.B. (2002) "Accounting is broken: Here's how to fix it", Stern Stewart Research, 5(1): 1-29.

29 TRAIN, J. (2003) Money Masters of Our Time, Harper Business: New York.

30 WARWICK, B. (2000) Searching for Alpha, John Wiley: New York. 